\title{
PHYSICAL EDUCATION AND LEISURE TIME ACTIVITIES AMONG PUPILS WITH AND WITHOUT HEARING LOSS
}

\author{
Aneta Změlíkováa ${ }^{\mathrm{ACD}}$, Petra Kurkováa ${ }^{\mathrm{ABD}}$ \\ ${ }^{1}$ Palacký University Olomouc \\ Authors' Contribution: A - Study design; B - Data collection; C - Statistical analysis; D - Manuscript Preparation; E - Funds Collection
}

Corresponding Author: Petra Kurková, E-mail: petra.kurkova@upol.cz

Accepted for Publication: June 2, 2021

Published: June 25, 2021

DOI: 10.17309/tmfv.2021.2.10

\begin{abstract}
The objective of this study was to analyse differences among Czech pupils' with/without hearing loss related to feelings and opinions on physical education classes; sport preferences in physical education classes; and leisure time activities at the lower secondary schools for the deaf.

Materials and methods. Participants were 83 pupils with hearing loss $(\mathrm{n}=41 ; 49.4 \%)$ and pupils without hearing loss $(\mathrm{n}=42 ; 50.6 \%)$; an average age of them was $14.3 \pm 1.3$ years. The non-parametric Mann-Whitney U-test, Fisher exact test, Chi-square test were used for statistical analyses. For calculation of effect size coefficient abs(r) was used. All tests were performed at a level of 0.05 .

Results. Pupils without hearing loss are more likely to express disappointment due to cancellation of a physical education class than pupils without hearing loss $(Z=-2.168 ; p=0.029)$. A statistically significant difference was found in preference for the various physical education activities and in leisure activities, where pupils without hearing loss prefer dancing $\left(\chi^{2}=8.622 ; \mathrm{p}=0.003\right)$, whereas pupils with hearing loss prefer volleyball $\left(\chi^{2}=14.833 ; \mathrm{p}=0.00001\right)$. In terms of leisure time activities, pupils with hearing loss spent their leisure time watching television significantly more often $\left(\chi^{2}=5.198 ; \mathrm{p}=0.023\right)$.

Conclusion. Both groups do not differ in feelings and opinions on physical education in terms of popularity, difficulty, importance, effort during physical education. On the contrary, differences in feelings associated with the cancellation of physical education or preference of activities in physical activities in physical education and leisure time appeared.

Key words: lower secondary school, special education, opinion, feelings, leisure time, sport.
\end{abstract}

\section{Introduction}

Individual development in various domains - depending on the aetiology - can be affected by hearing loss. Important factors are the age of the person, severity and type of impairment, quality of care, the time when the rehabilitation started, the suitability of rehabilitation methods, cognitive abilities, psychomotor skills or social and environmental factors (Coskun et al., 2019; Ochoa-Martínez et al., 2019; Van der Straaten et al., 2020). Due to physical and psychosocial limitations - difficulties in communication with peers, lower health and physical literacy, children with hearing loss may experience reduced physical activity and fitness (Ellis et al., 2014; Hartman et al., 2011). Therefore, schools for the deaf tend to encourage more physical activity through physical education classes and structured sports programs in the pupils' leisure time (Kurková, 2015).

Physical education is a priority field in the development of children health promotion, including those who are deaf or

(c) Změlíková, A., Kurková, P., 2021. hard of hearing. Benefits of physical education and physical activity in leisure time can improve the bio-psycho-social and spiritual domains (Marmeleira et al., 2019). Moreover, it is also fundamental to active living from early childhood to adulthood (Cheung, 2019). Generally, school-based physical education is an effective means of influencing the body and mind and develop the range of motor and cognitive competencies, impaired due to the hearing loss. Thus, physical education is essential for pupils with hearing loss. Additionally, physical education may be the best setting for individuals with hearing loss to learn about physical activity (Kurková et al., 2010; Li et al., 2019).

Research focusing on the physical education experience of pupils with hearing loss has shown that those pupils tend to find many barriers in physical education classes. In the study, Kurková et al. (2010) found some challenges for physical education classes in the ratio of students-teachers and the potential risks involved in several activities during the classes. Another research by Kurková (2015) described the worries felt by pupils with hearing loss regarding misunderstandings in com- 
munication, delayed reactions when beginning a new activity, and the worries of destroying their hearing aids when participating in contact sports during physical education classes.

According to the Czech Statistical Office (2018), Czech schoolchildren consider physical education and computers to be a popular school subject. This finding confirmed a study by Kurková and Nemček (2018), where teenagers who are deaf/hard of hearing do sport significantly more often in their leisure time in comparison with teenagers with visual impairment. Engel-Yeger and Hamed-Daher (2013) compared the involvement in leisure time activities between children with hearing loss, with visual impairment and typical peers. They found out for both groups - children who are deaf/hard of hearing and with visual impairment - it was more challenging to participate in leisure activities, and it is necessary to provide support and facilitate their involvement through intervention and community programmes.

Due to the previous research, the study aimed to analyse differences among pupils' with and without hearing loss related to (a) feelings and opinions on physical education classes; (b) sport preferences in physical education classes and leisure time activity at the second grade of schools for the deaf.

\section{Materials and Methods}

\section{Study sample}

The research sample comprised eighty-three Czech pupils - with hearing loss $(\mathrm{n}=41 ; 49.4 \%)$ and without hearing loss $(n=42 ; 50.6 \%)$ from the two lower secondary schools (European Commission, 2018) - boys, $\mathrm{n}=49$; 59.0\%; girls, $\mathrm{n}=30 ; 31.6 \%$; and 4 pupils (4.9\%) did not state their sex. The mean age with a standard deviation of the age was $14.3 \pm 1.3$ years, the age range was 11 to 17 years, and the median age was 14 years. The exclusion criterion for all participants was additional combined disabilities (e.g. cognitive, physical or visual impairment). In the Czech Republic, in all lower secondary schools for the deaf is possible to extend school attendance to ten years, upon approval from the ministry. In such a case, the first grade comprises years 1 to 6 , and the second grade comprises years 7 to 10 (Act No. 561/2004 Coll., on preschool, primary, secondary, higher, and other education [Zákon č. 561/2004 Sb.]).

Within the sample, the most pupils with hearing loss have been deaf or hard of hearing from birth $(n=33 ; 80.5 \%)$. With respect to the severity of hearing impairment (hearing loss expressed in decibels), moderate to severe hearing loss
$(40-80 \mathrm{~dB})(\mathrm{n}=13 ; 31.7 \% ; \mathrm{n}=11 ; 26.8 \%)$ is represented among the pupils. A compensation aid is used by most pupils $(\mathrm{n}=27 ; 65.9 \%)$, in most cases a hearing aid $(\mathrm{n}=23 ; 85.2 \%)$, fewer pupils have a cochlear implant $(n=4 ; 14.8 \%)$. In relation to participation in sport, both samples do not differ much - sport on a competitive level $(\mathrm{n}=18 ; 43.9 \% ; \mathrm{n}=19$; $45.2 \%)$, recreational sports $(\mathrm{n}=19 ; 46.3 \% ; \mathrm{n}=19 ; 45.2 \%)$, no sports at all $(\mathrm{n}=4 ; 9.8 \% ; \mathrm{n}=4 ; 9.5 \%)$.

\section{Data collection}

The data collection were carried out in April and May 2017 at the second grade (years 7-10) of the Czech lower secondary schools for the deaf. To access the research for our group with and without hearing loss, a structured questionnaire in modified form - adapted text version and video format in the Czech sign language - was used. The pupils completed the questionnaire in the presence of the class tutor and the researcher. If necessary, a teacher, an interpreter from/to sign language was available to pupils with hearing loss to avoid any misunderstanding of the questions. The research had relevant approval from the Ethics Committee. All subjects signed an informed consent form before enrolment. In this study, we compare seven questions concerning the differences among pupils with and without hearing loss in physical education classes. The questions were related to their opinions and feelings about physical education classes and assessed: a) the popularity of physical education; b) the importance of physical education; c) the difficulty of physical education; d) effort in physical education classes; e) emotionality in physical education classes; f) emotional response if a physical education class is cancelled; g) reason for the lack of interest in physical education classes - If you do not enjoy physical education classes, what is usually the most common reason for that? Furthermore, we compared the pupil's preferences in a physical education class and their leisure time activities. Participants were asked, "What activity do you most often do in your leisure time?"; and "Which of the following physical activities would you like to do in physical education classes?” (Kurková \& Langová, 2021). Another information about research participants included demographic facts.

\section{Statistical Analysis}

The data were described using absolute and relative frequencies, including the mean, standard deviation and median. For statistical analyses, we used the non-parametric

Table 1. Intergroup comparison of mean values in pupils' feelings and opinions on physical education classes

\begin{tabular}{|c|c|c|c|c|c|c|}
\hline \multirow[t]{2}{*}{ Variable } & $\begin{array}{l}\text { Pupils with hearing loss } \\
\qquad(\mathrm{n}=41)\end{array}$ & $\begin{array}{l}\text { Pupils without hearing loss } \\
\qquad(\mathrm{n}=42)\end{array}$ & Total $(\mathrm{N}=\mathbf{8 3})$ & \multirow[t]{2}{*}{ Z } & \multirow[t]{2}{*}{$\mathbf{p}$} & \multirow[t]{2}{*}{$\operatorname{abs}(\mathbf{r})$} \\
\hline & $\mathrm{M} \pm \mathrm{SD}$ & $\mathrm{M} \pm \mathrm{SD}$ & $\mathrm{M} \pm \mathrm{SD}$ & & & \\
\hline Popularity & $2.17 \pm 0.83$ & $1.95 \pm 0.98$ & $2.06 \pm 0.92$ & 1.230 & 0.193 & $0.134 \dagger$ \\
\hline Importance & $1.88 \pm 0.90$ & $2.05 \pm 0.91$ & $1.96 \pm 0.90$ & -0.861 & 0.365 & 0.094 \\
\hline Difficulty & $3.24 \pm 0.97$ & $3.55 \pm 0.86$ & $3.40 \pm 0.92$ & -1.266 & 0.171 & $0.138 \dagger$ \\
\hline Effort & $1.95 \pm 0.83$ & $1.91 \pm 0.69$ & $1.93 \pm 0.76$ & 0.118 & 0.903 & 0.013 \\
\hline Emotionality 1 & $2.15 \pm 0.79$ & $2.00 \pm 0.94$ & $2.08 \pm 0.87$ & 1.043 & 0.271 & $0.114 \dagger$ \\
\hline Emotionality 2 & $3.10 \pm 0.89$ & $3.41 \pm 0.99$ & $3.25 \pm 0.95$ & -2.168 & $0.029^{*}$ & $0.231 \dagger$ \\
\hline
\end{tabular}

Note. SD - standard deviation; Z - Mann-Whitney U-test statistics; abs(r) - absolute value of Cohen’s r; †small effect size; $\mathrm{p}$ - statistical significance $\left({ }^{*} \mathrm{p}\right.$-values $\left.<0.05\right)$. 
Mann-Whitney U-test, Chi-square test, and, for low frequencies, the Fisher's exact test. Furthermore, the effect size coefficient was used. The $\mathrm{Z}$ value can be used to calculate an effect size, such as the $r$ proposed by Cohen (1988) where values $\mathrm{r}=0.50,0.30$, and 0.10 may be interpreted as large, medium and small effects. All tests were performed at a level of 0.05 , and we used the software $\mathrm{R}$ for statistical processing.

\section{Results}

Table 1 and Table 2 present the intergroup comparison of pupils with and without hearing loss in physical education classes. Using the Mann-Whitney's U-test, it was proven in the Emotionality 2 indicator - when cancelling a physical education class - pupils without hearing loss are more likely to express disappointment due to cancellation of a physical education class $(Z=-2.168 ; p=0.029)$. The statistical significance in this indicator was also confirmed by the small effect size coefficient $(\mathrm{abs}(\mathrm{r})=0.231)$ - Table 1 .

Related to other analysed indicators - Popularity $(\operatorname{abs}(r)=0.134)$, Difficulty $(\mathrm{abs}(\mathrm{r})=0.138)$, and Emotionality $1(\operatorname{abs}(r)=0.114)-$ a small effect size coefficient was found; however statistical significance was not proven (Table 1).

Table 2. Pupils' preferences in physical education classes and their leisure time activity

\begin{tabular}{|c|c|c|c|c|c|c|}
\hline \multirow[t]{2}{*}{ Variable } & \multicolumn{2}{|c|}{$\begin{array}{l}\text { Pupils with hearing loss } \\
\qquad(\mathrm{n}=41)\end{array}$} & \multicolumn{2}{|c|}{$\begin{array}{c}\text { Pupils without hearing } \\
\text { loss }(\mathrm{n}=42)\end{array}$} & \multirow{2}{*}{$\chi^{2}$} & \multirow[t]{2}{*}{$\mathbf{p}$} \\
\hline & $\mathbf{n}$ & $\%$ & $\mathbf{n}$ & $\%$ & & \\
\hline \multicolumn{7}{|c|}{ Preferences in physical education classes } \\
\hline Athletics & 9 & 22.0 & 7 & 16.7 & 0.372 & 0.542 \\
\hline Aerobics & 1 & 2.4 & 1 & 2.4 & & $1.000^{\mathrm{a}}$ \\
\hline Badminton & 4 & 9.8 & 2 & 4.8 & & $0.433^{\mathrm{a}}$ \\
\hline Swimming & 11 & 26.8 & 9 & 21.4 & 0.331 & 0.565 \\
\hline Gymnastics & 1 & 2.4 & 2 & 4.8 & & $1.000^{\mathrm{a}}$ \\
\hline Tennis & 3 & 7.3 & 4 & 9.5 & & $1.000^{\mathrm{a}}$ \\
\hline Frisbee & 3 & 7.3 & 3 & 7.1 & & $1.000^{\mathrm{a}}$ \\
\hline Combat sports & 3 & 7.3 & 5 & 11.9 & & $0.713^{\mathrm{a}}$ \\
\hline Floorball & 19 & 46.3 & 14 & 33.3 & 1.466 & 0.226 \\
\hline Handball & 4 & 9.8 & 5 & 11.9 & & $1.000^{\mathrm{a}}$ \\
\hline Dancing & 3 & 7.3 & 14 & 9.5 & 8.622 & $0.003^{\star}$ \\
\hline Football & 15 & 36.6 & 12 & 28.6 & 0.607 & 0.436 \\
\hline Volleyball & 18 & 19.5 & 3 & 7.1 & 14.833 & $0.0001^{\star}$ \\
\hline Basketball & 7 & 17.1 & 7 & 16.7 & 0.002 & 0.961 \\
\hline Dodgeball & 13 & 31.7 & 20 & 47.6 & 2.193 & 0.139 \\
\hline Zumba & 1 & 2.4 & 1 & 2.4 & & $1.000^{\mathrm{a}}$ \\
\hline Health exercises & 7 & 17.1 & 7 & 16.7 & 0.002 & 0.961 \\
\hline \multicolumn{7}{|c|}{ Reasons for the lack of interest in physical education } \\
\hline Unattractive content & 6 & 14.6 & 3 & 7.1 & & $0.313^{\mathrm{a}}$ \\
\hline Teacher's approach & 5 & 12.2 & 2 & 4.8 & & $0.265^{\mathrm{a}}$ \\
\hline I don't feel like exercising & 3 & 7.3 & 3 & 7.1 & & $1.000^{\mathrm{a}}$ \\
\hline Poor conditions in the gym & 6 & 14.6 & 1 & 2.4 & & $0.057^{\mathrm{a}}$ \\
\hline I focus on the subsequent classes & 6 & 14.6 & 5 & 11.9 & 0.134 & 0.714 \\
\hline \multicolumn{7}{|c|}{ Leisure activity } \\
\hline Television & 12 & 29.3 & 4 & 9.5 & 5.198 & $0.023^{\star}$ \\
\hline Listening to music & 11 & 26.8 & 18 & 42.9 & 2.345 & 0.126 \\
\hline Listening to the radio & 1 & 2.4 & 3 & 7.1 & & $0.616^{\mathrm{a}}$ \\
\hline Doing sport & 23 & 56.1 & 19 & 45.2 & 0.979 & 0.322 \\
\hline Visiting sport matches & 10 & 24.4 & 5 & 11.9 & 2.184 & 0.139 \\
\hline Theatre. cinema, concert & 3 & 7.3 & 1 & 2.4 & & $0.360^{\mathrm{a}}$ \\
\hline Reading & 3 & 7.3 & 8 & 19.0 & 2.483 & 0.115 \\
\hline Art & 8 & 19.5 & 7 & 16.7 & 0.113 & 0.736 \\
\hline Friends & 13 & 31.7 & 17 & 40.5 & 0.691 & 0.406 \\
\hline Computer, mobile phone & 14 & 34.1 & 11 & 26.2 & 0.624 & 0.430 \\
\hline Homework, gardening & 10 & 24.4 & 8 & 19.0 & 0.349 & 0.555 \\
\hline Self-education & 3 & 7.3 & 3 & 7.1 & & $1.000^{\mathrm{a}}$ \\
\hline Idleness & 1 & 2.4 & 2 & 4.8 & & $1.000^{\mathrm{a}}$ \\
\hline
\end{tabular}

Note. $\chi^{2}$ - the value of the test statistic for the chi-squared test; aFisher's exact test; $\mathrm{p}$ - statistical significance $\left({ }^{*} \mathrm{p}\right.$-values $\left.<0.05\right)$. 
Looking at the sports preferences in physical education classes, using the Chi-square test, it was a statistical proof that pupils without hearing loss prefer dancing $\left(\chi^{2}=8.622\right.$; $\mathrm{p}=0.003)$, whereas pupils with hearing loss prefer volleyball $\left(\chi^{2}=14.833 ; \mathrm{p}=0.00001\right)$. There were no other statistical differences found, pupils with hearing loss and without hearing loss prefer mostly floorball (46.3\% versus 33.3\%), dodgeball (31.7\% versus $47.6 \%)$, football (36.6\% versus $28.6 \%)$, and swimming (26.8\% versus $21.4 \%)$ - Table 2.

In the question relating to the reasons for the lack of interest in physical education classes, pupils with and without hearing loss indicated unattractive content $(14.6 \%$ versus $7.1 \%)$ and focusing on the subsequent class (14.6\% versus $11.9 \%$ ) as the most frequent reasons. In the variable concerning poor conditions in the gym, the differences approached the level of statistical significance $(p=0.057)$. Pupils with hearing loss indicated this reason more often than pupils without hearing loss (14.6\% versus $2.4 \%$ ).

In terms of leisure time activities, using the Chi-square test, it was statistically proven that pupils with hearing loss spent their leisure time watching television significantly more often $\left(\chi^{2}=5.198 ; p=0.023\right)$. Generally, pupils with hearing loss and without hearing loss mostly prefer doing sport (56.1\% versus $45.2 \%)$, going out with friends (31.7\% versus $40.5 \%)$, listening to music ( $26.8 \%$ versus $42.9 \%)$, and computers/ mobile phones (34.1\% versus $26.2 \%$ ) - Table 2 .

\section{Discussion}

In the present study, we have compared the differences among Czech pupils with and without hearing loss in the various variables for physical education classes and leisure time activities. By comparing the average values of the answers of our pupils from schools for the deaf with Slovak pupils with sensory disabilities in special education (Kurková et al., 2015), pupils with sensory disabilities considered physical education to be more popular than pupils in our work. In the research of Hrabal and Pavelková (2010), the average value in the given indicator was lower, and Czech pupils from regular schools perceived physical education as more popular than our pupils. Similar results to our research are also the findings of a survey by the Czech Statistical Office, where Czech schoolchildren consider computers and physical education to be very popular school subjects (Czech Statistical Office, 2018).

By comparing the average values of the answers of our pupils from schools for the deaf with the results of the Slovak study of ordinary pupils (Antala et al., 2012) and Czech pupils from mainstream schools (Hrabal \& Pavelková, 2010) in the indicator Importance, our pupils from pupils for the deaf lower average values, which means that our students rate physical education as more important. Minimal differences also appeared in the comparison of our study with Slovak pupils with sensory disabilities (Kurková et al., 2015). We can state that pupils from schools for the deaf evaluate physical education as more important in comparison with pupils from ordinary schools both in the Czech Republic and in Slovakia.

Both pupils with hearing loss and pupils without hearing loss consider physical education to be an undemanding subject. As part of our comparison of the average values of the total sample in the Difficulty indicator, pupils in our study considered physical education to be more demanding than pupils from Czech and Slovak mainstream schools (Antala et al., 2012;
Hrabal \& Pavelková, 2010) and pupils from Slovak schools for the hearing and visually impaired (Kurková et al., 2015).

In the indicator Effort, in the comparison of the general population of Czech primary school pupils (Hrabal \& Pavelková, 2010), the average values of our group do not differ. Compared to Slovak pupils from schools for the sensory impaired, our pupils achieve lower average values. Differences in showing effort during physical education classes may be influenced by the current activity, climatic conditions, fear of injury; current health condition and the preferred communication system can have some influence on the active participation in physical education classes of pupils from schools for the deaf, too. (Ellis et al., 2014; Jaarsma et al., 2014; Kurková, 2015).

Comparing the overall set of our study with the Slovak study of pupils with sensory disabilities (Kurková et al., 2015) in the indicator Emotionality 1 - feelings in physical education - our pupils achieved higher average values. This result means that they feel good in physical education classes, while the students of the Slovak study always feel good. Our results are also affirmed by the study of Cypriot students, where these students perceived physical education as beneficial and fun (Constantinides \& Silverman, 2018). In the indicator Emotionality 2 - emotions of pupils in the case of dropping out of a physical education class - statistically significant differences in average values were found between pupils with hearing loss and pupils without hearing loss. Pupils without hearing loss are more likely to express disappointment at the dropout of a physical education class. However, when comparing the results of our pupils in the overall sample with the Slovak study of pupils with sensory disabilities (Kurková et al., 2015), our pupils show a higher degree of disappointment from dropping out of physical education class than pupils with sensory disabilities from Slovakia.

In the question concerning the causes of lack of interest in physical education classes, pupils with hearing loss most often state concentration for other class, boredom, or were not satisfied with the gym. Similar results appeared in the study by Kurková and Nemček (2016), where pupils with hearing loss most often stated unsatisfactory conditions or that they were lazy as the cause of lack of interest in physical education classes. Slovak visually impaired pupils in the same study claimed that they were lazy or the reason for their lack of interest was concentrating on the following class. The results we found also confirm the results of the study by Antala et al. (2012), where the most common causes of lack of interest in physical education classes for Slovak pupils in regular primary schools were comfort, unattractive content and concentration on the following class.

When comparing leisure activities, there is a statistical significance that pupils with hearing loss are more likely to spend their free time watching television. These pupils also play sports more often and spend time on a computer. Similar preferences verify the study of Kurková and Sigmund (2010), where pupils with hearing loss preferred sports activities and spending time on computer in their free time. The exact opposite results showed the study of Stough et al. (2016). He found that schoolchildren with hearing loss spent less time watching television due to limited sound perception and difficulty reading subtitles. However, these authors found that students with less severe hearing loss listened to music significantly more often. Pupils without hearing loss play sports more often, listen to music, spend time with friends and on the computer. Nemček (2014) also found out that pupils with physical disabilities in 
their free time engaged exclusively in sedentary activities, such as listening to music, playing on a computer and watching television. There were no other differences between pupils with hearing loss and without hearing loss in leisure preferences demonstrated.

In the comparison of activities which are preferred during physical education classes by pupils from schools for the deaf, there was a statistically significant difference in dance preference, where pupils without hearing loss prefer dance significantly more often compared to pupils with hearing loss. Pupils from schools for the deaf prefer floorball, volleyball and football in physical education classes. Our findings are consistent with the results of an earlier study of Czech and Slovak pupils with sensory disabilities (Kurková \& Nemček, 2018; Kurková et al., 2015).

\section{Conclusion}

In physical education classes, there were statistically significant differences in the Emotionality 2 indicator - when cancelling a physical education class - pupils without hearing loss are more likely to express disappointment due to cancellation of a physical education classes than pupils without hearing loss. The statistical significance in this indicator confirmed the small effect size coefficient. Related to other analysed indicators - Popularity, Difficulty, and Emotionality 1 - a small effect size coefficient appeared. However, statistical significance was not proven. A statistically significant difference was found in preference for the various physical education activities and in leisure activities, where pupils without hearing loss prefer dancing, whereas pupils with hearing loss prefer volleyball. In terms of leisure time activities, there was a statistical proof that pupils with hearing loss spent their leisure time watching television significantly more often than pupils without hearing loss. Furthermore, differences in feelings associated with the cancellation of physical education in physical education appeared. The results cannot be generalized - they only attest to the schools within the given region. The low number of participating schools and the number of pupils with and without hearing loss limited the study. Another limit was the lack of knowledge of the level of current fitness and overall health condition of the participated pupils.

\section{Funding}

The authors received no financial support for the research, authorship, and/or publication of this article.

\section{Conflicting Interests}

The authors declared no potential conflicts of interest.

\section{References}

Coskun, B., Unlu, G., Golshaei, B., Kocak, S., \& Kirazcı, S. (2019). Comparison of the static and dynamic balance between normal-hearing and hearing-impaired wrestlers. Montenegrin Journal of Sports Science and Medicine, 8(1), 11-16. https://doi.org/10.26773/mjssm.190302

Ochoa-Martínez, P. Y., Hall-López, J. A., López, A. A. C., Castro, Z. E. R., Buñuel, P. S.-L., \& García, C. C. (2019). Análisis comparativo de un programa educación física en niños con discapacidad auditiva sobre la edad motora equivalente [Comparative analysis of the effect of physical education program of motor age equivalent in children with hearing disability]. Retos: Nuevas Perspectivas de Educación Física, Deporte y Recreación, 35(1), 310-313. https://doi.org/10.47197/retos.v0i35.67190

Van der Straaten, T. F. K., Rieffe, C., Soede, W., Netten, A. P., Dirks, E., Oudesluys-Murphy,...Frijns, J. H. M. (2020). Quality of life of children with hearing loss in special and mainstream education: A longitudinal study. International Journal of Pediatric Otorhinolaryngology, 128, 109701. https://doi.org/10.1016/j.ijporl.2019.109701

Ellis, M. K., Lieberman, L. J., \& Dummer, G. M. (2014). Parent influences on physical activity participation and physical fitness of deaf children. Journal of Deaf Studies and Deaf Education, 19(2), 270-81. https://doi.org/10.1093/deafed/ent033

Hartman, E., Houwen, S., \& Visscher, C. (2011). Motor Skill Performance and Sports Participation in Deaf Elementary School Children. Adapted Physical Activity Quarterly, 28(2), 132-145. https://doi.org/10.1123/apaq.28.2.132

Kurková, P. (2015). Emotions in the physical activities of Czech students who are deaf or hard of hearing in general and special education. Journal of Physical Education and Sport, 15(4), 823-828. https://doi.org/10.7752/jpes.2015.04126

Marmeleira, J., Laranjo, L., Bravo, J., \& Menezes, D. (2019). Physical Activity Patterns in Adults who are Deaf. European Journal of Adapted Physical Activity, 12(1), 1-10. https://doi.org/10.5507/euj.2019.002

Cheung, P. (2019). Teachers as role models for physical activity: Are preschool children more active when their teachers are active? European Physical Education Review. https://doi.org/10.1177/1356336X19835240

Kurková, P., Scheetz, N. A., \& Stelzer, J. (2010). Health and physical education as an important part of school curricula: A comparison of schools for the deaf in the Czech Republic and the United States. American Annals of the Deaf, 155(1), 78-87. https://doi.org/10.1353/aad.0.0132

Kurková, P., \& Sigmund, E. (2010). Tělesná výchova a preference volnočasových aktivit u žáků se sluchovým postižením [Physical education and leisure-time preferences of students who are deaf or hard of hearing]. Tělesná kultura, 33(1), 7-25. https://doi.org/10.5507/tk.2010.001

Li, C., Haegele, J. A., \& Wu, L. (2019). Comparing physical activity and sedentary behavior levels between deaf and hearing adolescents. Disability and Health Journal 12(3), 514-518. https://doi.org/10.1016/j.dhjo.2018.12.002

Czech Statistical Office, 2018. Minisčitání 2018 [Mini counting 2018]. https://vdb.czso.cz/mini_2018/vysledky. jsp? $\mathrm{kr}=\mathrm{x} \& \mathrm{o}=5 \& \mathrm{u}=1 \& \mathrm{~m}=6$

Kurková, P., \& Nemček, D. (2018). Preferences and reasons for the lack of interest of Czech teenagers with sensory disabilities in physical education classes. Physical Activity Review, 6, 171-180. https://doi.org/10.16926/par.2018.06.22

Kurková, P., \& Langová, K. (2021). Predictors of physical education class and leisure-time preferences of teenagers who are deaf or hard of hearing. American Annals of the Deaf, 166(1), 31-48. https://doi.org/10.1353/aad.2021.0009

Engel-Yeger, B., \& Hamed-Daher, S. (2013). Comparing participation in out of school activities between children with visual impairments, children with hearing impairments and typical peers. Research in Developmental Disabilities, 34(10), 3124-3132. https://doi.org/10.1016/j.ridd.2013.05.049 
European Commission. (2018). The structure of the European education systems 2018/19: Schematic diagrams. https:// eacea.ec.europa.eu/national-policies/eurydice/sites/ eurydice/files/the_structure_of_the_european_education_ systems_201819_schematic_diagrams_-_final_report.pdf

Zákon č. 561/2004 Sb., o předškolním, základnim středním, vyšším odborném a jiném vzdělávání (školský zákon) [Act No 561/2004 Coll., On Preschool, Primary, Secondary, Tertiary, Vocational, and Other Education], 2004.

Cohen, J. (1988). Statistical power analysis for the behavioral sciences (2nd ed.). New York: Academic Press.

Kurková, P. Nemček, D., \& Labudová, J. (2015). Pupils with sensory disabilities in Physical Education classes: Attitudes and preferences. Acta Gymnica, 45(3), 139-145. https://doi.org/10.5507/ag.2015.015

Hrabal, V., \& Pavelková, I. (2010). Jaký jsem učitel [What type of teacher I am]. Prague, Czech Republic: Portál.

Antala, B., Šimonek, J., Čilík, I., Labudová, J., Medeková, H., Bebčáková, V., ... Melek, P. (2012). Telesná a športová výchova $v$ názoroch žiakov základných a stredných škôl [Physical and sports education as reflected in opinions of pupils of the elementary and secondary schools]. Bratislava, Slovakia: End.
Jaarsma, E. A., Dekker, R., Koopmans, S. A., Dijkstra, P. U., \& Geertzen, J. H. B. (2014). Barriers to and facilitators of sports participation in people with visual impairments. Adapted Physical Activity Quarterly, 31, 240-264. https://doi.org/10.1123/apaq.2013-0119

Constantinides, P., \& Silverman, S. (2018). Cypriot urban elementary students' attitude toward physical education. Journal of Teaching in Physical Education, 37, 69-77. https://doi.org/10.1123/jtpe.2016-0235

Kurková, P., \& Nemček, D. (2016). Attitudes of students with disabilities towards physical education lessons: Reasons for their indifference and preference for leisure time activities. Journal of Physical Education and Sport, 16(1), 222-229. https://doi.org/10.7752/jpes.2016.01035

Stough, T., Ceulemans, K., Lambrechts, W. \& Cappuyns, V. (2016), Assessingsustainability in higher education curricula: A critical reection on validity issues. Journal of Cleaner Production, 172, 4456-66. https://doi.org/10.1016/j.jclepro.2017.02.017

Nemček, D.(2014). Štruktúra volnočasových aktivít mládeže s telesným postihnutím [The structure of leisure time activities in children with physical disabilities]. Telesná výchova a šport [Physical Education and Sport], 24(1), 11-14.

\title{
ФІЗИЧНЕ ВИХОВАННЯ ТА ДОЗВІЛЛЯ СЕРЕД УЧНІВ ІЗ ВТРАТОЮ СЛУХУ ТА БЕЗ НЁ̈
}

\author{
Анета Змелікова ${ }^{1 \mathrm{ACD}}$, Петра Куркова ${ }^{1 \mathrm{ABD}}$ \\ ${ }^{1}$ Палацький університет Оломоуц \\ Авторський вклад: А - дизайн дослідження; В - збір даних; C - статаналіз; D - підготовка рукопису; Е - збір коштів \\ Реферат. Стаття: 6 с., 2 табл., 26 джерел.
}

Метою цього дослідження було проаналізувати відмінності серед чеських учнів із / без втрати слуху, пов'язані з почуттями та думками щодо занять фізичною культурою; спортивні уподобання на уроках фізичної культури; та дозвілля у початкових загальноосвітніх школах для глухих.

Матеріали і методи. Учасниками стали 83 учні із втратою слуху (n = 41;49,4\%) та учні без втрати слуху (n = 42; 50,6\%); середній вік їх становив $14,3 \pm 1,3$ року. Для статистичного аналізу використовували непараметричний U-критерій Манна-Уітні, точний критерій Фішера, критерій хі-квадрат. Для розрахунку величини ефекту використовували коефіцієнт abs (r) . Всі тести проводились на рівні 0,05.

Результати. Учні без втрати слуху частіше виявляють розчарування через скасування уроку фізкультури, ніж учні без втрати слуху $(Z=-2,168 ; \mathrm{p}=0,029)$. Статистично значуща різниця була виявлена в перевазі до різноманіт- них занять фізичною культурою та дозвіллєвих заняттях, де учні без втрати слуху віддають перевагу танцям $\left(\chi^{2}=8,622\right.$; $\mathrm{p}=0,003)$, тоді як учні з втратою слуху надають перевагу волейболу $\left(\chi^{2}=14,833 ; \mathrm{p}=0,00001\right)$. Що стосується дозвіллєвих занять, учні із вадами слуху проводили своє дозвілля значно частіше за телевізором $\left(\chi^{2}=5,198 ; p=0,023\right)$.

Висновки. Обидві групи не відрізняються між собою почуттями та думками щодо фізичного виховання з точки зору популярності, складності, важливості, зусиль під час фізичного виховання. Навпаки, з'явилися розбіжності у почуттях, пов'язаних із скасуванням фізичного виховання чи перевагою занять фізичними вправами під час фізичного виховання та дозвілля.

Ключові слова: неповна загальноосвітня школа, спеціальна освіта, думка, почуття, дозвілля, спорт.

\section{Information about the authors:}

Změlíková Aneta: zmelikova.aneta@gmail.com; Department of Anthropology and Health Education, Faculty of Education, Palacký University Olomouc, Žižkovo nám. 5, Olomouc, 779 00, Czech Republic.

Kurková Petra: petra.kurkova@upol.cz; https://orcid.org/0000-0003-0856-8074; Department of Anthropology and Health Education, Faculty of Education, Palacký University Olomouc, Žižkovo nám. 5, Olomouc, 779 00, Czech Republic.

Cite this article as: Změlíková, A., \& Kurková, P. (2021). Physical Education and Leisure Time Activities among Pupils with and without Hearing Loss. Teoriâ ta Metodika Fizičnogo Vihovannâ, 21(2), 167-172. https://doi.org/10.17309/tmfv.2021.2.10

Received: 17.05.2021. Accepted: 02.06.2021. Published: 25.06.2021

This work is licensed under a Creative Commons Attribution 4.0 International License (http://creativecommons.org/licenses/by/4.0), 